\title{
Enrichment of Wheatgrass (Triticum aestivum L) Juice and Powder in Milk and Meat-based food Products for Enhanced Antioxidant Potential
}

\author{
Chingakham Basanti Devi ${ }^{1}$, Manish Kumar Chatli ${ }^{2}$, Kiran Bains ${ }^{1}$, \\ Harpreet Kaur ${ }^{1}$ and S.N. Rindhe ${ }^{1 *}$ \\ ${ }^{1}$ Department of Food and Nutrition, Punjab Agricultural University, Ludhiana, Punjab, India \\ ${ }^{2}$ Department of Livestock Product Technology, Guru Angad Dev Veterinary and Animal \\ Sciences University, Ludhiana, Punjab-141004, India
}

*Corresponding author

\section{Keywords}

Wheatgrass powder, Wheatgrass juice,

Milk, Meat,

Antioxidant activity

Article Info

Accepted:

18 May 2019

Available Online:

10 June 2019

\section{A B S T R A C T}

\begin{abstract}
Wheatgrass at young green stage is a powerhouse of nutrients and phytochemicals. With an aim to develop wheatgrass enriched health foods, Wheatgrass juice (WGJ) and wheatgrass powder (WGP) were incorporated in milk and meat products, respectively. WGJ (1:2 ratio of wheatgrass: water) was incorporated at 3,6 and $9 \%$ in milk to formulate green milk, green paneer and enrobe paneer. WGP was incorporated at 1,2 and 3\% for chicken balls and nuggets. Overall acceptability score of green milk and green paneer with $9 \%$ WGJ was $8.15,7.93$ and 8.55 , respectively on nine-point hedonic scale and were statistically comparable with their control counterparts. A significant $(p<0.05)$ increase in antioxidant activity (by DPPH method) was observed at all the levels of incorporation of WGJ in milk-based foods, though the highest was at $9 \%$ level of incorporation when compared with the control i.e. 17.05 vs $0.98,22.33$ vs. 1.07 and 16.49 vs. $1.28 \%$. The average sensory scores for overall acceptability of chicken nuggets and balls with $3 \%$ WGP was 7.53 and 7.98 , respectively and were statistically comparable to the control counterparts. Antioxidant activity of the chicken nuggets and ballsen riched with 3\% WGP was significantly $(\mathrm{p}<0.05)$ higher in comparison to the control i.e. 25.13 vs. $33.14 \%$ and 11.21 vs. 15.39 , respectively. It was concluded that the incorporation of WGJ at $9 \%$ in milk products and WGP at 3\% in meat products had optimum sensory attributes and may impart health promoting properties to the products owing to their high antioxidant activity.
\end{abstract}

\section{Introduction}

Wheat (Triticum species), annual cereal grass of the gramineacea (poaceae) family is the world's largest edible cereal grass crop. The young grass of wheat (Triticum species) is commonly referred to as wheatgrass. Since ancient times, wheatgrass has been used to treat various diseases and still continue to be used as a health tonic. For over fifty years, researchers have known that cereal grass at young green stage is a potent source of various nutrients like proteins, minerals, vitamins, active enzymes and phytochemicals like alkaloids, glycosides, saponins, steroids, tannins and flavonoids etc (Jain and Argal 
2014). The clinical utility of wheatgrass varies from mild illness to life threatening diseases like cancer. Antioxidant property of wheatgrass accounts for the treatment of most of the degenerative diseases like diabetes and cardio-vascular diseases (Afroz et al., 2012). It is proven to be beneficial under various conditions, such as anemia, diabetes, cancer, eczema, constipation, kidney swelling and common cold. Wheat grass stimulates metabolism, restores alkalinity to the blood, its abundance of alkaline minerals help to reduce over acidity in the blood. Wheatgrass is also a detoxificant and helps restore healthy cells (Fahey et al., 2006). Thus, it should be made part of daily dietary intake in order to explore its maximum benefits (Kumar et al., 2016). Considering its nutritional potency, wheatgrass has been called as the 'Panacea on Earth' by many famous naturopaths and dieticians around the world. It was claimed that 15 pounds of wheatgrass is equivalent to 350 pounds of carrots, lettuce and celery (Mujoriya and Bodla, 2011).

The use of wheatgrass juice and powder for the therapeutic purposes is popular as a part of herb therapeutic nutritional approach. At present, various formulations of wheatgrass products are available in the form of health supplements (extracts or powders) as well as medicines (tablets). There are number of suppliers, in almost all the cities of India supplying fresh wheatgrass on daily basis by home delivery system for various ailments and as health tonic. The procurement of fresh wheatgrass is not practically feasible for the consumers, but dried powder of wheatgrass can be easily used for enrichment of foods that have high consumption frequency by the masses. The wheatgrass products prepared from wheatgrass powder and juice can be commercialized and may contribute to the ever-growing market of health foods exploiting numerous health promoting benefits of wheatgrass. Therefore, a huge potential of utilization of wheatgrass is in the form of dried powder and juice. The developed food products can be recommended to the population for general good health as well as for cure of disorders like metabolic syndrome, cancer, thalassemia, anemia etc.

The present study was conducted to develop acceptable functional milk (flavoured milk, paneer, enrobed paneer) foods and meat (chicken meat nuggets, balls) products with the incorporation of wheat grass powder and juice.

\section{Materials and Methods}

\section{Chicken meat}

The broiler birds of age 7 weeks weighing $1.6 \mathrm{~kg}$ were procured from poultry farm of Guru Angad Dev Veterinary and Animal Sciences University (GADVASU), Ludhiana and slaughtered in the instructional poultry processing plant of the Department of Livestock Products Technology, College of Veterinary Sciences, GADVASU, Ludhiana, Punjab as per humane scientific protocol, with the consideration of animal welfare aspects. The dressed carcasses were packed in low density polyethylene (LDPE) bags and stored overnight at $4 \pm 1^{\circ} \mathrm{C}$ temperature. These are manually deboned and deboned meat packed in LDPE bags in the unit pack of $1 \mathrm{Kg}$ and subsequently stored in deep freezer at $18 \pm 1^{\circ} \mathrm{C}$ till further use. The unit packs were taken out as per requirements and thawed over night in a refrigerator $4 \pm 1^{\circ} \mathrm{C}$ for experimental use.

\section{Preparation of wheatgrass powder and juice}

Different ingredients used in the development of products i.e. milk, salt, sugar, spices and other additives were obtained from the local 
market of Ludhiana in a single lot. Fresh wheatgrass required for the formulation of wheatgrass powder and juice was cultivated in the optimized indoor conditions in the Department of Food and Nutrition, Punjab Agricultural University, Ludhiana. Wheatgrass harvested on $7^{\text {th }}$ day was freeze dried at $-40^{\circ} \mathrm{C}$ for 72 hours to prepare wheatgrass powder (WGP). Wheatgrass juice (WGJ) was prepared by crushing the wheatgrass in electrical grinder with 1:2 ratio of wheatgrass and water followed by filtration through $1 \mathrm{~mm}$ mesh.

\section{Product development}

Wheatgrass powder (WGP) and wheatgrass juices (WGJ) at different levels were incorporated in various milk and meat-based foods using pre standardized method (Sharma et al., 2002, Mahajan et al., 2017). The level of incorporation wheatgrass and types of milk and meat were selected on the basis of various preliminary trials conducted to determine the suitability of different levels of WGP or WGJ for the product development. The food products namely flavoured milk, paneer, enrobed paneer, chicken meat nuggets and chicken meat balls were selected to be enriched with different levels of either WGP or WGJ. Flavoured milk, paneer and enrobed paneer were supplemented with 3, 6 and 9\% of WGJ. Chicken nuggets and balls were supplemented with 1, 2 and $3 \%$ WGP. The detailed product development has been shown in table 1 and 2.

\section{Sensory evaluation}

The developed products were evaluated for their sensory properties by a panel of ten semi- trained panelists from the Department of Food and Nutrition, Punjab Agricultural University, Ludhiana and Department of Livestock Product Technology, Guru Angad Dev Veterinary and Animal Sciences
University, Ludhiana, Punjab. The panelists were asked to score the samples on the basis of their color, appearance, texture, taste and overall acceptability by using a score card of 9-point descriptive scale where 9 indicated "like extremely" and 1 indicated "dislike extremely". Each panelist was provided with coded samples and mouth rinse facility in between the samples. Further, enough privacy was provided to the panelists to avoid biased assessment.

\section{Antioxidant activity (DPPH Assay)}

The free radical scavenging activity was determined by using the DPPH assay (Dehshahri et al., 2012). Two grams of sample was extracted with $20 \mathrm{ml}$ of methanol by shaking for two hours. Extraction process was repeated twice. The extract was pulled together and centrifuged at $10000 \mathrm{rpm}$ for 15 minutes. The supernatant was stored at $-20^{\circ} \mathrm{C}$ till analysis. $100 \mu \mathrm{l}$ of the aliquot of extract was taken in test tubes and added $2.9 \mathrm{ml}$ of DPPH solution. The mixture was vortexed for 1 minute and incubated in dark for 3 minutes. Discolouration of DPPH was measured against blank at $517 \mathrm{~nm}$. The DPPH scavenging effect was measured using by formula: $\%$ inhibition $=A_{B}-A_{A} / A_{B} \times 100$

Where, $\mathrm{A}_{\mathrm{B}}=$ absorbance of blank; $\mathrm{A}_{\mathrm{A}}=$ absorbance of sample

\section{Statistical analysis}

All the experiments were conducted three times and samples were drawn in duplicate for analysis. Mean and standard deviations for the various parameters were computed. Analysis of Variance (ANOVA) was employed to assess the difference in parameters using Microsoft Excel (2003) Statistical Analysis Tool Pack. Least Significant Difference (LSD) at 5\% was calculated for the comparison among the parameters. 


\section{Results and Discussion}

\section{Antioxidant activity}

\section{Milk products}

The antioxidant activity of wheatgrass juice enriched flavored milk at all the three levels i.e 3, 6 and $9 \%$ was significantly $(\mathrm{p} \leq 0.05)$ higher in comparison to the control, the antioxidant activity being 10.19, 14.77 and $17.05 \%$ at the three levels (Table 4). The antioxidant activity of control, 3, 6 and $9 \%$ wheatgrass incorporated paneer was 1.07 , $13.35,15.77$ and $22.33 \%$, respectively. The corresponding values for enrobed paneer were $1.28,12.06,15.09$ and $16.49 \%$. It was observed that the antioxidant activity increased with increasing level of wheatgrass incorporation. The antioxidant activity of paneer with $9 \%$ wheatgrass incorporation was significantly $(\mathrm{p} \leq 0.05)$ higher in comparison to control, 3 and $6 \%$ incorporation. No significant difference in antioxidant activity was observed in 3 and $6 \%$ incorporated paneer. On the other hand, in case of enrobed paneer, the antioxidant activity of $9 \%$ incorporation was significantly $(p \leq 0.05)$ higher in comparison to control and $3 \%$ incorporation, however, at par with $6 \%$ incorporated enrobe paneer. Moreover, the antioxidant activity of $6 \%$ incorporated enrobe paneer was significantly $(\mathrm{p} \leq 0.05)$ higher than that of control one. The antioxidant enzymes present in milk or antioxidant components present in wheatgrass juice might have been destroyed due to prolonged processing methods. Further, lower antioxidant activity of enrobe paneer may be due to the prolonged heat application during sautéing in the enrobing process. However, retention in some activity may be due to various spices used in enrobing. The antioxidant activity in both flavoured milk and paneer increased with increasing level of wheatgrass juice incorporation. Similar findings were reported by Srivastava et al., (2015) when two herbs namely Zingiber officinale and beta vulgariswere added to yogurt and milk. Ali et al., (2014) also reported a higher antioxidant activity in icecream when asparagus, pomegranate and green asparagus powder were incorporated. The above findings indicated that wheatgrass juice can be added successfully as a source of antioxidants in milk-based health foods.

The antioxidant activity of wheatgrass chicken nuggets for control, 1, 2 and $3 \%$ WGP incorporation was 25.13, 31.94, 32.25 and 33.14, respectively (Table 4). The corresponding values for chicken balls were 11.21, 13.30, 14.38 and $15.39 \%$, respectively. The antioxidant activity of wheatgrass enriched chicken nuggets was significantly $(\mathrm{p} \leq 0.05)$ higher in comparison to its control counterpart, however, no significant difference in antioxidant activity was observed in three different levels. On the other hand, the statistical analysis showed that the antioxidant activity of 2 and $3 \%$ incorporation were significantly $(p \leq 0.05)$ higher than control counterparts in regard to chicken balls. From the results, it was observed that the antioxidant activity of wheatgrass enriched chicken balls was lower than the wheatgrass incorporated chicken nuggets. This may be attributed to difference in the method of cooking for the two products as balls used dry heat method while nuggets were steam cooked. There is a probability that a significant amount of antioxidant compounds was destroyed during baking at high temperature or there may be leaching of some antioxidant compounds during steam cooking. However, nuggets retained higher amount of antioxidants than that of balls, hence steaming is a better method of cooking for wheatgrass based meat products. WGP incorporation upto $3 \%$ should be considered in formulation of nuggets and balls to attain a significant enhancement of antioxidant 
activity in these products. Banerjee et al (2012) observed a significant increase in antioxidant activity when broccoli extract upto $2 \%$ was supplemented in goat meat nuggets.

\section{Sensory attributes and overall acceptability}

Flavoured milk, paneer and paneer enrobes were formulated by incorporating wheatgrass juice (WGJ) in order to standardize the level of incorporation of wheatgrass in these milk products for achieving maximum sensory attributes (Table 3). The wheatgrass enriched flavoured milk imparted colour of light green to deep green. Cow's milk with sugar and flavouring agents was used as control sample $\left(\mathrm{M}_{1}\right)$. Overall acceptability score was the highest for flavoured milk supplemented with 6\% WGJ (8.51) followed by milk supplemented with 3\% WGJ. The flavored milk supplemented with 9\% WGJ had the lowest score of 8.15. No significant difference with regard to all the sensory attributes for all the treatments was observed. Hence, the flavoured milk with $9 \%$ of incorporation of WGJ was considered as a standard recipe. Paneer is an important indigenous product which is obtained by giving heat treatment to the milk followed by acid coagulation using suitable acids viz. citric acid, lactic acid, tartaric acid, alum and sour whey etc. The overall acceptability of treatment $\mathrm{M}_{2}$ (8.50) was at par with the control product, $\mathrm{M}_{1}(8.52)$ followed by $M_{3}$ (8.05) andM (7.55). The mean scores of flavour for all the four treatments differed significantly $(\mathrm{p} \leq 0.05)$. The flavor score of $\mathrm{M}_{4}$ was significantly $(\mathrm{p} \leq 0.05)$ lower than the control and $\mathrm{M}_{2}$ and $\mathrm{M}_{3}$. The results indicated that minimum upto $9 \%$ of wheatgrass juice can be added without affecting much of its sensory attributes. In order to avoid the biasness of judgment of the panel members, the formulated paneer was enrobed by using whole wheat flour and spices followed by shallow frying. Unlike paneer, the enrobe paneer treatments were significantly $(\mathrm{p} \leq 0.05)$ different with regard to all sensory parameters except texture. The mean scores of appearance, colour, texture, flavor and overall acceptability was significantly $(p \leq 0.05)$ lower for $\mathrm{M}_{4}$ in comparison to $\mathrm{M}_{1}, \mathrm{M}_{2}$, and $\mathrm{M}_{3}$. It was observed that even though there was a decreasing trend in the overall acceptability scores, paneer was found to be accepted even at its highest level i.e. 9\% whereas, enrobe paneer was acceptable upto $6 \%$ level. Thus, it is concluded that paneer and enrobe paneer can be enriched with wheatgrass juice upto $9 \%$ level without any significant decrease in the acceptability. Similar results were obtained by Bajwa et al., (2005) when paneer was enriched with coriander and mint leaves from $5 \%$ to $30 \%$ in buffalo milk having $5 \%$ fat. A decrease in sensory scores was observed with increase in the level of incorporation although all the products were well acceptable.

Two meat-based foods i.e. chicken nuggets and chicken balls were also prepared using wheatgrass powder at varying ratios (Table $3)$. The control nuggets $\left(\mathrm{CN}_{1}\right)$ had the highest mean scores with regard to all the parameters followed by $\mathrm{CN}_{2}, \mathrm{CN}_{3}$ and $\mathrm{CN}_{3}$. However, no significant difference was found between the various treatments, therefore, clearly indicating, the suitability of wheatgrass incorporation upto $3 \%$ in chicken nuggets without affecting its sensory quality. The results were in agreement with the findings of Baneerjee et al., (2012), where broccoli powder upto $2 \%$ was acceptable in mutton nuggets. In case of chicken balls, the treatment $\mathrm{CB}_{2}(1 \%)$ had the highest overall acceptability with score of 8.35 followed by $\mathrm{CB}_{1}$ (8.15). Statistical analysis revealed a significant $(\mathrm{p} \leq 0.05)$ difference among the treatments for all the sensory attributes except texture and flavour. Noticeable observation was an increase in mean score for all sensory 
attributes except colour when wheatgrass incorporation was made at $1 \%\left(\mathrm{CB}_{2}\right)$ level in comparison to the control $\left(\mathrm{CB}_{1}\right)$ product. Inspite of using same amount of ingredients in preparation, significant difference in sensory attributes was observed in case of balls, however not in nuggets. This may be attributed to the difference in the method of cooking for the two products. In the nuggets, steam cooking was employed whereas, the balls were baked in hot air oven. Steam cooking might leach out the flavour compounds as well as colour components and hence no significant difference was observed in these sensory attributes. The sensory score of mutton nuggets after addition of broccoli powder at 1, 1.5 and $2 \%$ had no significant difference as observed by Banerjee et al (2012). When chicken nuggets were incorporated with bottle gourd and oat flour, a significant increase in the overall acceptability of the products was observed (Verma et al., 2012 and Modi et al., 2009).

Table.1 Standardized recipes for wheatgrass juice enriched flavoured milk, paneer and enrobe paneer

\begin{tabular}{|c|c|c|c|c|c|c|c|}
\hline \multirow[t]{2}{*}{ Recipe } & \multirow[b]{2}{*}{ Ingredients (g) } & \multicolumn{4}{|c|}{ Level of incorporation } & \multirow{2}{*}{$\begin{array}{c}\text { Cooking } \\
\text { time }\end{array}$} & \multirow[t]{2}{*}{ Temp. } \\
\hline & & Control & $3 \%$ & $6 \%$ & $9 \%$ & & \\
\hline $\begin{array}{l}\text { Flavoured } \\
\text { Milk }\end{array}$ & $\begin{array}{l}\text { Standardized Milk } \\
\text { (SNF-8.5\% and fat } \\
4.5 \%)(\mathrm{ml}) \\
\text { Wheatgrass juice } \\
(\mathrm{ml}) \\
\text { Sugar } \\
\text { Cardamom } \\
\text { Cardamom essence }\end{array}$ & $\begin{array}{c}100 \\
\\
\\
- \\
8 \\
1 \\
1 \text { drop }\end{array}$ & $\begin{array}{c}3 \\
8 \\
1 \\
1 \text { drop }\end{array}$ & $\begin{array}{c}6 \\
8 \\
1 \\
1 \text { drop }\end{array}$ & $\begin{array}{c}9 \\
8 \\
1 \\
1 \text { drop }\end{array}$ & $\begin{array}{l}25-30 \\
\text { minutes }\end{array}$ & $\begin{array}{l}40- \\
45^{\circ} \mathrm{C}\end{array}$ \\
\hline Paneer & $\begin{array}{l}\text { Standardized milk } \\
(\mathrm{SNF}-8.5 \% \text { and fat } \\
4.5 \%)(\mathrm{ml}) \\
\text { WGJ }(\mathrm{ml}) \\
2 \% \text { Citric acid (ml) }\end{array}$ & $\begin{array}{c}100 \\
- \\
50-\frac{6}{6 l} \mathrm{ml}\end{array}$ & $\begin{array}{c}97 \\
\\
\\
3 \\
50-60 \mathrm{ml}\end{array}$ & $\begin{array}{c}6 \\
50-60 \mathrm{ml}\end{array}$ & $\begin{array}{c}91 \\
\\
\quad 9 \\
50-60 \mathrm{ml}\end{array}$ & $\begin{array}{l}20-30 \\
\text { minutes }\end{array}$ & $\begin{array}{l}76- \\
78^{\circ} \mathrm{C}\end{array}$ \\
\hline $\begin{array}{l}\text { Enrobedp } \\
\text { aneer }\end{array}$ & $\begin{array}{l}\text { Standardized milk } \\
(\mathrm{SNF}-8.5 \% \text { and fat } \\
4.5 \%)(\mathrm{ml}) \\
\text { WGJ (ml) } \\
\text { Cardamom } \\
2 \% \text { citric acid (ml) } \\
\text { Mix spices } \\
\text { (cumin,ginger, } \\
\text { garlic, coriander } \\
\text { powder, chilli } \\
\text { powder) } \\
\text { Refined wheat flour } \\
\text { Salt }\end{array}$ & $\begin{array}{c}- \\
1 \\
50-60 \mathrm{ml} \\
\text { To taste } \\
\text { To coat } \\
\text { To taste }\end{array}$ & $\begin{array}{c}3 \\
1 \\
50-60 \mathrm{ml} \\
\text { To taste } \\
\text { To coat } \\
\text { To taste }\end{array}$ & $\begin{array}{c}94 \\
\\
6 \\
1 \\
50-60 \mathrm{ml} \\
\text { To taste } \\
\text { To coat } \\
\text { To taste }\end{array}$ & $\begin{array}{c}9 \\
1 \\
50-60 \mathrm{ml} \\
\text { To taste } \\
\text { To coat } \\
\text { To taste }\end{array}$ & $\begin{array}{c}\text { Deep fry } \\
\text { until } \\
\text { brown }\end{array}$ & - \\
\hline
\end{tabular}

WGJ- wheatgrass juice 
Table.2 Standardized recipes for wheatgrass powder enriched chicken nuggets and chicken balls

\begin{tabular}{|c|c|c|c|c|c|c|c|}
\hline \multirow[t]{2}{*}{ Recipe } & \multirow[b]{2}{*}{ Ingredients (g) } & \multicolumn{4}{|c|}{ Level of incorporation } & \multirow[t]{2}{*}{ Temperature } & \multirow{2}{*}{$\begin{array}{c}\text { Cooking } \\
\text { time }\end{array}$} \\
\hline & & Control & $1 \%$ & $2 \%$ & $3 \%$ & & \\
\hline \multirow{13}{*}{$\begin{array}{l}\text { Chicken } \\
\text { nuggets }\end{array}$} & Chicken & 850 & 841.5 & 833 & 824.5 & \multirow{13}{*}{$\begin{array}{c}\text { Autoclaving } \\
(150 \mathrm{lb}) \text { at } \\
120^{\circ} \mathrm{C}\end{array}$} & \multirow{13}{*}{$\begin{array}{c}15 \\
\text { minutes }\end{array}$} \\
\hline & WGP & - & 8.5 & 17 & 25.5 & & \\
\hline & Refined wheat flour & 61.9 & 70 & 70 & 70 & & \\
\hline & Spices (cumin and & 25.3 & 30.6 & 30.6 & 30.6 & & \\
\hline & red chilli) & 18.75 & 21.25 & 21.25 & 21.25 & & \\
\hline & Salt & 37.5 & 45.3 & 45.3 & 45.3 & & \\
\hline & Condiments & 125 & 141.6 & 141.6 & 141.6 & & \\
\hline & (onion+ginger+garlic) & & & & & & \\
\hline & Fat & 58.12 & 65.8 & 65.8 & 65.8 & & \\
\hline & Whole egg liquid & 61.9 & 70 & 70 & 70 & & \\
\hline & Textured soy protein & 0.37 & 0.425 & 0.425 & 0.425 & & \\
\hline & Pyrophosphate & 0.15 & 0.17 & 0.17 & 0.17 & & \\
\hline & Sodium nitrite & & & & & & \\
\hline \multirow{13}{*}{$\begin{array}{l}\text { Chicken } \\
\text { balls }\end{array}$} & Chicken & 850 & 841.5 & 833 & 824.5 & \multirow{13}{*}{$\begin{array}{c}\text { Baking at } \\
160^{\circ} \mathrm{C}\end{array}$} & \multirow{13}{*}{$\begin{array}{c}20 \\
\text { minutes }\end{array}$} \\
\hline & WGP & - & 8.5 & 17 & 25.5 & & \\
\hline & Refined wheat flour & 61.9 & 70 & 70 & 70 & & \\
\hline & Spices (cumin and & 25.3 & 30.6 & 30.6 & 30.6 & & \\
\hline & red chilli) & 18.75 & 21.25 & 21.25 & 21.25 & & \\
\hline & Salt & 37.5 & 45.3 & 45.3 & 45.3 & & \\
\hline & Condiments & 125 & 141.6 & 141.6 & 141.6 & & \\
\hline & (onion+ginger+garlic) & & & & & & \\
\hline & Fat & 58.12 & 65.8 & 65.8 & 65.8 & & \\
\hline & Whole egg liquid & 61.9 & 70 & 70 & 70 & & \\
\hline & Textured soy & 0.37 & 0.425 & 0.425 & 0.425 & & \\
\hline & proteinPyrophosphate & 0.15 & 0.17 & 0.17 & 0.17 & & \\
\hline & Sodium nitrite & & & & & & \\
\hline
\end{tabular}

WGP- wheatgrass powder 
Table.3 Sensory evaluation of wheatgrass juice and powder enriched milk and meat-based products

\begin{tabular}{|c|c|c|c|c|c|}
\hline Product & Appearance & Colour & Texture & Flavour & $\begin{array}{c}\text { Overall } \\
\text { acceptability }\end{array}$ \\
\hline \multicolumn{6}{|c|}{ Flavoured milk } \\
\hline Control $\left(M_{1}\right)$ & $8.40 \pm 0.69$ & $8.00 \pm 0.82$ & $8.35 \pm 0.75$ & $8.15 \pm 0.75$ & $8.2 \pm 0.65$ \\
\hline $3 \%\left(\mathrm{M}_{2}\right)$ & $8.40 \pm 0.57$ & $8.55 \pm 0.72$ & $8.2 \pm 0.72$ & $8.60 \pm 0.52$ & $8.44 \pm 0.55$ \\
\hline $6 \%\left(M_{3}\right)$ & $8.52 \pm 0.65$ & $8.52 \pm 0.65$ & $8.4 \pm 0.65$ & $8.5 \pm 0.67$ & $8.51 \pm 0.65$ \\
\hline $9 \%\left(M_{4}\right)$ & $8.17 \pm 0.88$ & $8.00 \pm 0.94$ & $8.25 \pm 0.94$ & $8.17 \pm 0.96$ & $8.15 \pm 0.87$ \\
\hline L.S.D. at 5\% & NS & NS & NS & NS & NS \\
\hline \multicolumn{6}{|c|}{ Paneer } \\
\hline Control $\left(M_{1}\right)$ & $8.32 \pm 0.82$ & $8.35 \pm 0.82$ & $8.75 \pm 0.63$ & $8.64 \pm 0.67$ & $8.52 \pm 0.58$ \\
\hline $3 \%\left(M_{2}\right)$ & $8.60 \pm 0.52$ & $8.20 \pm 063$ & $8.8 \pm 0.42$ & $8.4 \pm 0.69$ & $8.5 \pm 0.44$ \\
\hline $6 \%\left(M_{3}\right)$ & $8.15 \pm 0.75$ & $8.15 \pm 0.94$ & $8.30 \pm 0.95$ & $7.9 \pm 1.28$ & $8.2 \pm 0.81$ \\
\hline $9 \%\left(\mathbf{M}_{4}\right)$ & $8.15 \pm 0.82$ & $7.95 \pm 0.95$ & $8.40 \pm 0.84$ & $7.25 \pm 0.97$ & $7.93 \pm 0.62$ \\
\hline L.S.D.at 5\% & NS & NS & 1.21 & NS & NS \\
\hline \multicolumn{6}{|c|}{ Enrobed paneer } \\
\hline Control $\left(M_{1}\right)$ & $8.40 \pm 2.35$ & $8.45 \pm 0.68$ & $8.65 \pm 0.67$ & $8.35 \pm 0.82$ & $8.46 \pm 0.64$ \\
\hline $3 \%\left(M_{2}\right)$ & $8.45 \pm 0.61$ & $8.6 \pm 0.46$ & $8.55 \pm 0.64$ & $8.50 \pm 0.67$ & $8.48 \pm 0.48$ \\
\hline $6 \%\left(M_{3}\right)$ & $7.90 \pm 0.59$ & $8.0 \pm 0.82$ & $8.35 \pm 0.91$ & $7.95 \pm 0.83$ & $8.05 \pm 0.71$ \\
\hline $9 \%\left(M_{4}\right)$ & $7.55 \pm 0.64$ & $8.55 \pm 0.96$ & $7.70 \pm 1.06$ & $7.4 \pm 0.94$ & $7.55 \pm 0.75$ \\
\hline L.S.D.at 5\% & 0.80 & 0.96 & NS & 1.04 & 0.84 \\
\hline \multicolumn{6}{|c|}{ Chicken nuggets } \\
\hline Control $\left(\mathrm{CN}_{1}\right)$ & $8.20 \pm 0.75$ & $8.10 \pm 0.69$ & $8.20 \pm 0.63$ & $8.35 \pm 0.47$ & $8.21 \pm 0.44$ \\
\hline $1 \%\left(\mathrm{CN}_{2}\right)$ & $7.93 \pm 0.73$ & $7.92 \pm 0.74$ & $8.10 \pm 0.74$ & $8.14 \pm 0.57$ & $8.02 \pm 0.61$ \\
\hline $2 \%\left(\mathrm{CN}_{3}\right)$ & $7.70 \pm 0.79$ & $7.55 \pm 0.68$ & $7.85 \pm 1.0$ & $8.10 \pm 0.69$ & $7.77 \pm 0.72$ \\
\hline $3 \%\left(\mathrm{CN}_{4}\right)$ & $7.27 \pm 0.92$ & $7.22 \pm 0.82$ & $7.82 \pm 1.20$ & $7.81 \pm 1.00$ & $7.53 \pm 0.9$ \\
\hline L.S.D.at $5 \%$ & NS & NS & NS & NS & NS \\
\hline \multicolumn{6}{|c|}{ Chicken balls } \\
\hline Control $\left(\mathbf{C B}_{1}\right)$ & $8.15 \pm 0.75$ & $8.35 \pm 0.67$ & $8.15 \pm 0.88$ & $8.95 \pm 1.01$ & $8.15 \pm 0.67$ \\
\hline $1 \%\left(\mathrm{CB}_{2}\right)$ & $8.30 \pm 0.67$ & $8.1 \pm 0.87$ & $8.45 \pm 0.49$ & $8.55 \pm 0.68$ & $8.35 \pm 0.56$ \\
\hline $2 \%\left(\mathrm{CB}_{3}\right)$ & $7.67 \pm 0.71$ & $7.8 \pm 0.92$ & $8.10 \pm 0.74$ & $8.45 \pm 0.68$ & $8.04 \pm 0.64$ \\
\hline $3 \%\left(\mathrm{CB}_{4}\right)$ & $7.25 \pm 1.18$ & $6.8 \pm 1.08$ & $7.75 \pm 1.03$ & $7.65 \pm 1.49$ & $7.38 \pm 1.07$ \\
\hline L.S.D.at 5\% & 1.10 & 1.13 & NS & NS & 0.98 \\
\hline
\end{tabular}

Values are Mean $\pm \mathrm{SD}$

NS Non-significant 
Table.4 Antioxidant activity (DPPH Assay) of wheatgrass juice and powder enriched milk and meat-based products

\begin{tabular}{|l|c|c|c|c|}
\hline \multirow{2}{*}{ Milk based foods } & \multicolumn{4}{|c|}{ Level of incorporation } \\
\cline { 2 - 5 } & Control & WGJ- 3 \% & WGJ- 6 \% & WGJ- 9\% \\
\hline Flavoured milk & $0.98 \pm 0.16^{\mathrm{a}}$ & $10.19 \pm 0.42^{\mathrm{b}}$ & $14.77 \pm 1.91^{\mathrm{b}}$ & $17.05 \pm 2.87^{\mathrm{b}}$ \\
\hline Paneer & $1.07 \pm 0.18^{\mathrm{a}}$ & $13.35 \pm 0.82^{\mathrm{b}}$ & $15.77 \pm 0.65^{\mathrm{b}}$ & $22.33 \pm 1.29^{\mathrm{c}}$ \\
\hline Enrobe paneer & $1.28 \pm 0.03^{\mathrm{a}}$ & $12.06 \pm 1.65^{\mathrm{b}}$ & $15.09 \pm 0.86^{\mathrm{bc}}$ & $16.49 \pm 0.86^{\mathrm{c}}$ \\
\hline Meat based foods & \multicolumn{4}{|c|}{ Level of incorporation } \\
\cline { 2 - 5 } & Control & WGP-1 \% & WGP-2 \% & WGP-3\% \\
\hline Chicken nuggets & $25.13 \pm 1.95^{\mathrm{a}}$ & $31.94 \pm 0.08^{\mathrm{b}}$ & $32.25 \pm 0.35^{\mathrm{b}}$ & $33.14 \pm 0.27^{\mathrm{b}}$ \\
\hline Chicken balls & $11.21 \pm 0.07^{\mathrm{a}}$ & $13.30 \pm 0.28^{\mathrm{b}}$ & $14.38 \pm 013^{\mathrm{bc}}$ & $15.39 \pm 0.5^{\mathrm{c}}$ \\
\hline
\end{tabular}

WGJ- Wheat Grass Juice; WGP $=$ Wheat Grass Powder

Values are Mean \pm SD; Values with different superscripts differ significantly $(\mathrm{P}<0.05)$ in the row

However, incorporating mustard powder resulted in a significant decrease in the acceptability of the chicken nuggets as reported by (Kumar and Tanwar 2011). Addition of wheatgrass upto 3\% did not affect the texture and flavour of the products, hence the chicken nuggets and balls were equally acceptable as the control products. The results also signified that wheatgrass powder added chicken nuggets or chicken balls upto $3 \%$ can maintain their original meaty flavour without dilution.

The study concluded that to enhance health promoting properties of milk and meat-based products, the wheatgrass juice can be enriched upto $9 \%$ in flavoured milk and paneer and upto $3 \%$ in chicken nuggets and balls. Therefore, the goodness of phytochemicals in wheatgrass can be successfully enriched in the animal-based foods for the development of functional foods with improved health benefits. These wheatgrass enriched products are high in antioxidant activity although there is no or little compromise for the overall acceptability of the formulated health foods. These products can be commercialized and may contribute to the ever-growing market of health foods.

\section{References}

Afroz, RD, Nurunnabi ASM, Hossain MZ, Kham MI, Parvin S, Rahman H (2012) Study on effects of wheatgrass (Triticum aestivum) juice on serum triglyceride of experimentally induced hypercholestroleamic male long evans rats. J Dhaka Med Coll21:197-203.

Ali, MN, Prasad SGM, Gnanaraja R, Srivastava P, Ibrahim M (2014) Assess the antioxidant activity of herbal ice cream using selected medicinal herbs. The Pharma Innovation J3:1-3.

Bajwa, U, Kaur J, Sandhu KS (2005) Effect of processing parameters and vegetables on the quality characteristics of vegetable fortified paneer. $\mathrm{J} \quad$ Food $\quad$ Sci Technol42:145-150.

Banerjee, R, Verma AK, Das AK, Rajkumar V, Shewalkar AA, Narkhede HP (2012) Antioxidant effects of broccoli powder extract in goat meat nuggets. Meat Sci91: 179-184.

Dehshahri, S, Wink M, Afsharypuor S, Asghari G, Mohagheghzadeh A (2012) Antioxidant activity in methanolic leaf extract of moringa 
peregrine (Forssk) fiori. Res Pharm Sci 7:111-118.

Fahey, JW, Stephenson KK, DinkovaKostova AT, Egner PA, Kensler TW, Talalay P (2005). Chlorophyll, chlorophyllin and related tetrapyrroles are significant inducers of mammalian phase 2 cytoprotective genes. Carcinogenesis 26:1247-1255.

Jain, G and Argal A. (2014) Pharmacognostic and phytochemical investigation of young leaves of Triticum aestivum Linn. Inter Curr Pharmaceut J3:280285.

Kumar, D and Tanwar VK (2011) Effects of incorporation of ground mustard on quality attributes of chicken nuggets. $J$ Food Sci. Technol., 48: 759-762.

Sharma, R.B., Manish Kumar and V. Pathak (2002) Effect of different seasons on cross-bred cows' milk composition and paneer yield. Asian-Australasian $J$ Animal Sci. 15(4) 528-531

Kumar, NS, Murali M, Nair AM, Nair AS (2016) Green blood therapy of wheatgrass - Nature's finest medicineA literature review. IOSR-JPBS 11:57-64.
Modi, V K, Yashoda K P and Naveen S K (2009) Effect of carrageenan and oat flour on quality characteristics of meat kofta. Int J Food Prop12:228-42.

Mujoriya, R and Bodla R B (2011) A study on wheatgrass and its nutritional value. Food Sci Quality Management 2:1-8.

Srivastava, P, Prasad S G M, Ali M N and Prasad M (2015) Analysis of antioxidant activity of herbal yoghurt prepared from different milks. The PharmaInnov J4:18-20.

Verma, A K, Banerjee R and Sharma B D (2012) Quality of low fat chicken nuggets: Effect of sodium chloride replacement and added chickpea (Cicer arietinum L.) hull flour. Asian Australas J Anim Sci25:291-98.

KanikaMahajan, M.K. Chatli, Nitin Mehta, Rajesh V. Wagh, O.P. Malav and Pavan Kumar (2017).Quality characteristics of functional spent hen meat nuggets incorporated with amla (Emblica officinalis) fruit juice powder. Journal of Animal Research, 7 (5): 1-7.

\section{How to cite this article:}

Chingakham Basanti Devi, Manish Kumar Chatli, Kiran Bains, Harpreet Kaur and Rindhe, S.N. 2019. Enrichment of Wheatgrass (Triticum aestivum L) Juice and Powder in Milk and Meat-based food Products for Enhanced Antioxidant Potential. Int.J.Curr.Microbiol.App.Sci. 8(06): 3259-3268. doi: https://doi.org/10.20546/ijcmas.2019.806.388 